\title{
ULCERATIVE LESIONS OF THE MOUTH: AN UPDATE FOR THE GENERAL MEDICAL PRACTITIONER
}

\author{
Jair Carneiro Leão ${ }^{1}$, Valder Barbosa Gomes ${ }^{1}$, Stephen Porter $^{2}$
}

Leão JC, Gomes VB, Porter S. Ulcerative lesions of the mouth: an update for the general medical practitioner. Clinics. 2007;62(6):769-80.

Oral ulceration is a common complaint of patients attending out-patient clinics. Because of the diversity in causes of oral ulceration, patients presenting with oral mucosal disease can be challenging to diagnose and manage. Patients with signs or symptoms of oral ulcers are sometimes referred to gastroenterology clinics; however, in most instances the ulcers do not result from gastrointestinal disease. The aim of the present article is to review aspects of the etiology, diagnosis and management of common ulcerative disorders of the oral mucosa. A search in the National Library of Medicine computerized bibliographic database MEDLINE was performed. Selection of publications, extraction of data, and validity assessment were then performed by the authors. Based upon the searched literature, it is concluded that there are several systemic disorders that can present with similar clinical signs and symptoms, and knowledge of each disease is necessary for the clinician to provide proper management.

KEYWORDS Oral Ulceration. Oral Medicine. Oral Lesions. Recurrent Aphthous Stomatitis. Recurrent Oral Ulceration.

\section{INTRODUCTION}

Oral ulcers are one of the most common complaints of the oral mucosa. The term ulcer is used where there is damage to both the epithelium and lamina propria. Several predisposing factors have been suggested and oral ulcers can be a feature of various systemic disorders including inflammatory bowel disease. Oral ulcers are determined by the underlying systemic condition such as the nature, site, duration and frequency. In addition, histopathological examination usually produces a definitive diagnosis for the majority of conditions described in this paper. The aim of this review is to provide a focus on ulcerative disorders, either of general clinical significance, or relevant to gastroenterology.

1. Departamento de Clínica e Odontologia Preventiva, Universidade Federal de Pernambuco, Recife, PE, Brazil

2. Oral Medicine unit, Division of Maxillofacial Diagnostics, Surgical and Medical Sciences, Eastman Dental Institute for Oral Health Care Sciences, University of London, UK

Email: jleao@ufpe.br

Received for publication on June 12, 2007

Accepted for publication on August 27, 2007

\section{Oral ulcers of traumatic (physical and chemical) etiology}

The majority of cases of ulcers of the oral mucosa are due to physical trauma. However, chemical trauma must also be considered. Salicylic acid (aspirin) and its derivatives are extensively used for the treatment of systemic and local diseases. However, injudicious use of these compounds may cause systemic and oral complications, such as mucosal burns and oral ulcers. ${ }^{1}$ In addition, ulcers may arise (e.g. on the palate) $)^{2}$ with the use of powdered cocaine or through the smoking crack cocaine. The effects of cocaine in the oral cavity vary depending on the form used and the route of administration. Rarely, snorting cocaine may cause necrosis, possibly associated with ischemia, of the floor of the nose; and eventually causing ulcers of the hard palate as well as oronasal fistula formation. ${ }^{3}$

Oral ulcers can be caused by local radiotherapy and some cytotoxic chemotherapy regimes (mucositis) (Fig.1). The mucosistis manifests as multiple areas of painful mucosal erythema, ulcers and sloughing. ${ }^{4}$ The precise etiology of mucositis remains unclear, although most likely reflects 


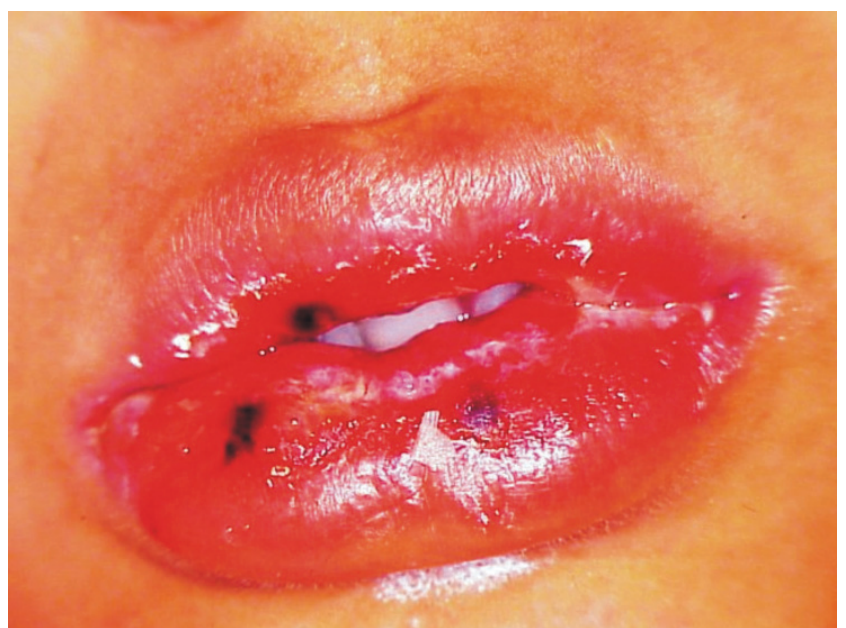

Figure 1 - Chemotherapy induced oral mucositis

a loss of basal cell proliferation ${ }^{5}$ rather than a reaction to changes in the local oral microflora (e.g. increases in Gramnegative bacteria, particularly Enterobacteriaceae). ${ }^{6}$ This mucositis, akin to that of the bowel, is difficult to manage specifically. Benzydamine hydrochloride mouth rinse or spray may provide symptomatic relief, but effective analgesia often requires opioids. The clinical features of oral mucositis do not significantly improve with topical chlorhexidine gluconate, although this compound is commonly used in clinical practice. Novel regimes for the treatment of mucositis include granulocyte-macrophage colonystimulating factor (GM-CSF) and protegrins. ${ }^{7,8}$

\section{Necrotizing sialometaplasia}

Necrotizing sialometaplasia is an uncommon disorder that typically gives rise to large areas of deep ulcers on one side of the hard and/or soft palate..$^{9}$ This condition is considered to be associated with an ischemic event, and is associated with clinical factors such as smoking, alcohol use, denture wearing, recent surgery, systemic disease, and it can also be a feature of bulimia nervosa. ${ }^{10}$ It has been suggested that the local traumas mentioned above cause ischemia with resultant tissue necrosis. The clinical features may mimic those of squamous cell carcinoma (SCC), and histopathologically, the profound epithelial hyperplasia, together with the salivary gland squamous metaplasia seen with necrotizing sialometaplasia, can be confused with neoplasia.

\section{Viral diseases}

\section{Herpes simplex virus 1}

The most common viral precipitant of ulcers is herpes simplex virus type 1 (HSV 1). Affected individuals may have widespread, small, superficial ulcers of the oral mucosa (Fig. 2). The gingiva are often swollen and ulcerated, giving rise to features akin to acute necrotizing ulcerative gingivitis (ANUG). While previously regarded as a disease of childhood, primary HSV-1 infection often arises in the second or third decade of life. ${ }^{11}$ Severe and/or recurrent HSV-1 infection, sometimes presenting atypically, may be suggestive of underlying immunodeficiency, in particular lymphoproliferative disease or HIV disease. ${ }^{12}$

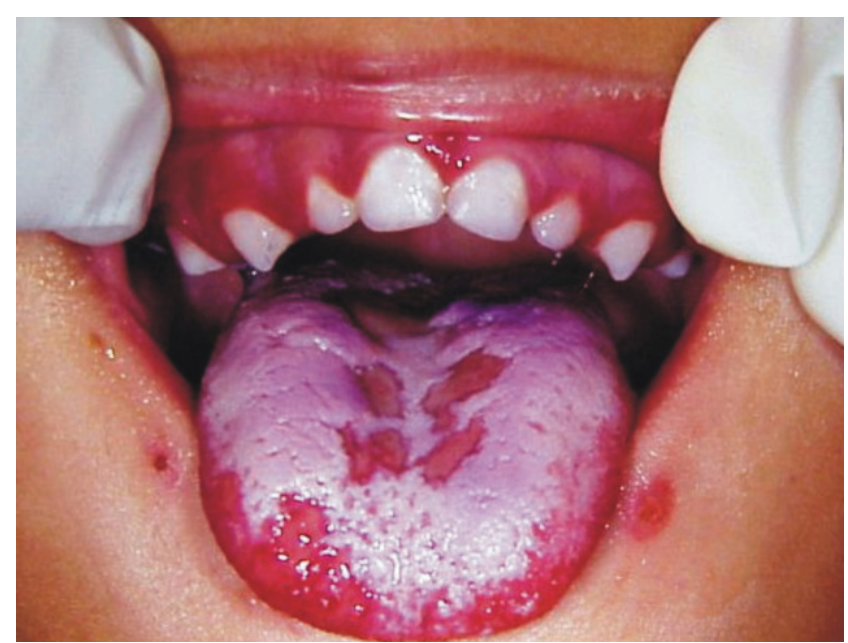

Figure 2 - Primary infection of HSV-1 affecting the gingival, tongue and skin

About 5\% of patients who have a primary HSV-1 infection will develop recurrent episodes of herpes labialis (cold sores), as illustrated in Figure 3. This comprises episodes of paresthesia, erythema, vesiculation, pustulization, and ulcers at the mucocutaneous junctions of the lips and/or nose. ${ }^{13-15}$ Precipitants of herpes labialis include concurrent illness, UV light exposure, and pregnancy. Effective therapy entails $5 \%$ aciclovir ${ }^{16}$ or $1 \%$ penciclovir. ${ }^{17}$ Herpes labialis may itself be a precipitant of erythema multiforme. ${ }^{18}$

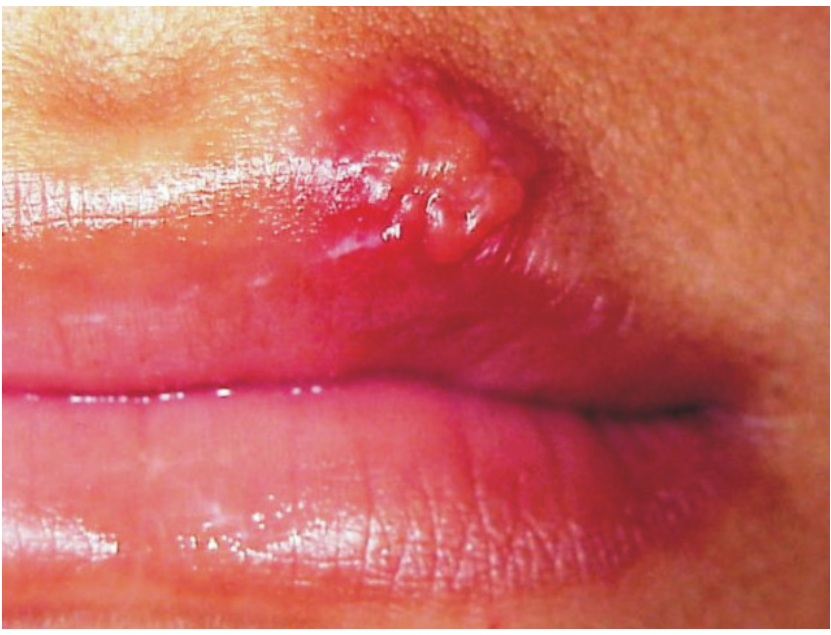

Figure 3 - Recurrent herpes labialis vesicule stage on the upper lip 
This therapy typically provides symptomatic relief, although systemic aciclovir and other anti-virals should be considered when disease is severe, recurrent, or atypical. ${ }^{13}$ Aciclovir resistance may arise in immunosuppressed patients receiving repeated treatments, hence the need for famciclovir, valciclovir or foscarnet. ${ }^{14}$ Interestingly, foscarnet may itself give rise to oral ulcers, ${ }^{15}$ and while aciclovir may be effective and useful in the treatment of erythema multiforme, it can also give rise to this mucosal disorder.

\section{Herpes simplex virus 2, Epstein-Barr virus and Cytomegalovirus}

Although uncommon, HSV-2 can give rise to oral ulcers similar to that of mild primary HSV-1 infection. This oral ulcer arises as a consequence of orogenital transmission of the causative virus.

Ulcers caused by Epstein-Barr virus (EBV) are rare, but may be a feature of infectious mononucleosis. The ulcers comprise a few small superficial ulcers of the oral mucosa. $\mathrm{EBV}$ is more typically associated with the ulcers of some non-Hodgkin's lymphomas ${ }^{19}$ or white patches termed oral hairy leukoplakia (OHL) that may arise in cases of immunodeficiency (e.g. HIV, or with corticosteroid or other systemic immunosuppressant therapy, etc.). It is also important to remember that OHL has been observed in patients with inflammatory bowel disease receiving immunosuppressive regimes..$^{20}$

Cytomegalovirus (CMV) may give rise to large, chronic ulcers of the oral mucosa or gingiva. ${ }^{21}$ These CMV-related ulcers occur exclusively under conditions of significant immunodeficiency, notably severe HIV disease. The diagnosis of such ulcers is difficult and is often only confirmed by resolution of ulcers with ganciclovir therapy. ${ }^{22}$

\section{Human herpesvirus 8 (Kaposi's sarcoma herpes virus)}

Human herpesvirus 8 (HHV-8) is an oncogenic virus, which causes Kaposi's sarcoma (KS). It is theorized that this virus, when infecting circulating KS cell-progenitors, predisposes a patient to KS development in the setting of exposure to Th1 inflammatory cytokines. Lytic replication caused by the virus can further promote tissue inflammation, thereby providing a proangiogenic stimulus that, among other things, increases generation of matrix metalloproteinases. In this multifactorial model of infection, hypoxia and injury can lead to the clinical expression of KS. Commonly arising within the mouth of patients with severe HIV disease or as a feature of profound iatrogenic immunosuppression (e.g. in patients with inflammatory bowel disease). Oral KS typically affects the palate or gingiva and manifests as red, blue or purple macules, papules, nodules or ulcers (Fig. 4). ${ }^{23}$ Oral KS may also occasionally be non-pigmented, and hence may mimic SCC. ${ }^{24}$

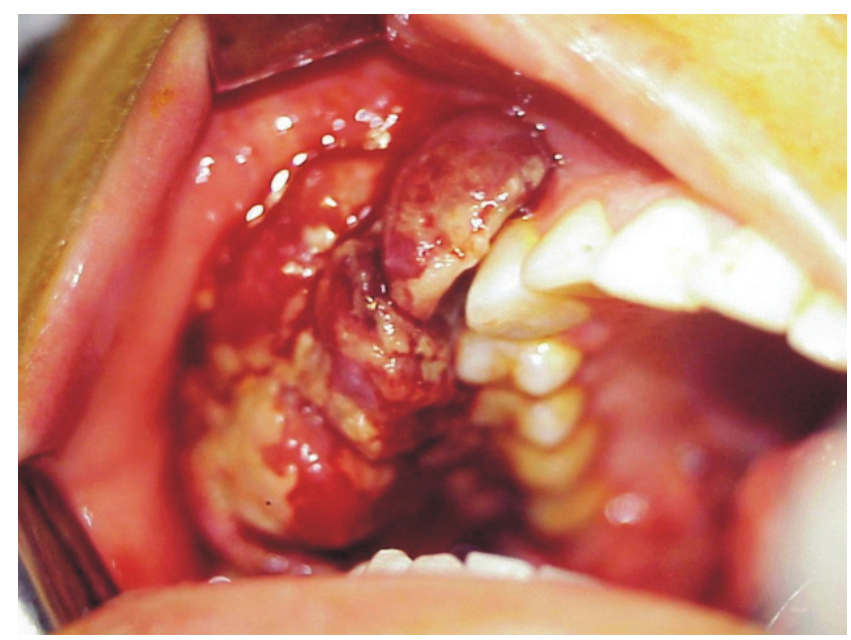

Figure 4 - HIV associated Kaposi’s sarcoma

Kaposi's sarcoma of the anterior gingiva may be unsightly, and in rare instances, gingival lesions will cause the destruction of underlying periodontal tissues, leading to tooth loss and sequestration of bone.

Oral KS in HIV may be reduced or resolved with highly active antiretroviral therapy (HAART); although some oral lesions have been reported to resolve (probably transiently) with local radiotherapy, local injection of cytotoxics, or sclerosants. ${ }^{25-27}$

\section{Human immunodeficiency virus}

The oral consequences of HIV have been reviewed in detail elsewhere. ${ }^{28,29}$ Infection with HIV gives rise to a wide spectrum of oral ulcerative lesions. The majority of these are detailed in other sections of the review. A minority of patients with severe HIV disease can develop deep, necrotic ulcers of unknown etiology. These ulcers are painful, can cause profound dysphagia and/or dysarthria, and can arise on any oral mucosal surface, although the buccal and pharyngeal mucosae are the more commonly affected sites. The precise etiology of these HIV-related ulcers is unknown. ${ }^{30}$ HHV-8 DNA has been detected within such ulcers, although it is unclear whether the virus is causative or merely a passenger. ${ }^{31}$ Of note, such ulcers typically resolve with systemic thalidomide (e.g. $200 \mathrm{mg}$ daily), perhaps reflecting an antitumor necrosis factor (TNF)-á effect, which supports a viral etiology. ${ }^{32}$ Small numbers of patients with HIV disease may have ulcers similar to those of recurrent aphthous stomatitis (RAS) (Fig. 5); to date, the cause of RAS has not been established. This limitation continues to compromise the clinician's ability to provide effective therapy. Whether the frequency of RAS is truly increased in HIV also remains unclear. ${ }^{33}$ 


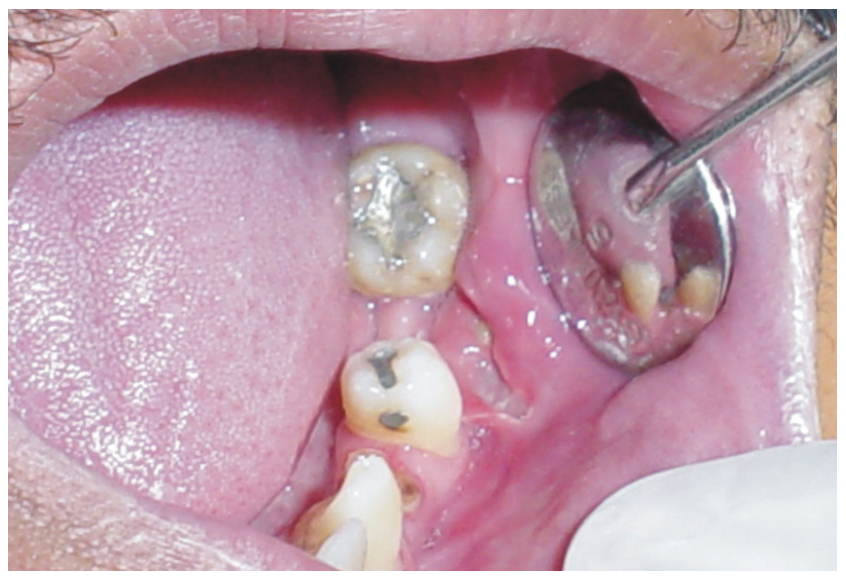

Figure 5 - Oral ulceration in HIV infected patient

\section{Bacterial infection}

\section{Acute necrotizing ulcerative gingivitis}

Acute necrotizing ulcerative gingivitis (Vincent's disease, trench mouth, acute ulcerative gingivitis) is a nonspecific ulcerative disorder that is almost always localized to the gingivae (Fig. 6). ${ }^{34}$ Associated contributing factors include poorly controlled diabetes mellitus, tobacco smoking, immunodeficiency (notably severe HIV disease), and possibly psychological stress. This condition is also associated with poor oral hygiene. Measles and malnutrition have also been implicated as predisposing factors to Acute Necrotizing Ulcerative Gingivitis (ANUG), common oral diseases prevalent among children ages 3-6 years living in rural communities.

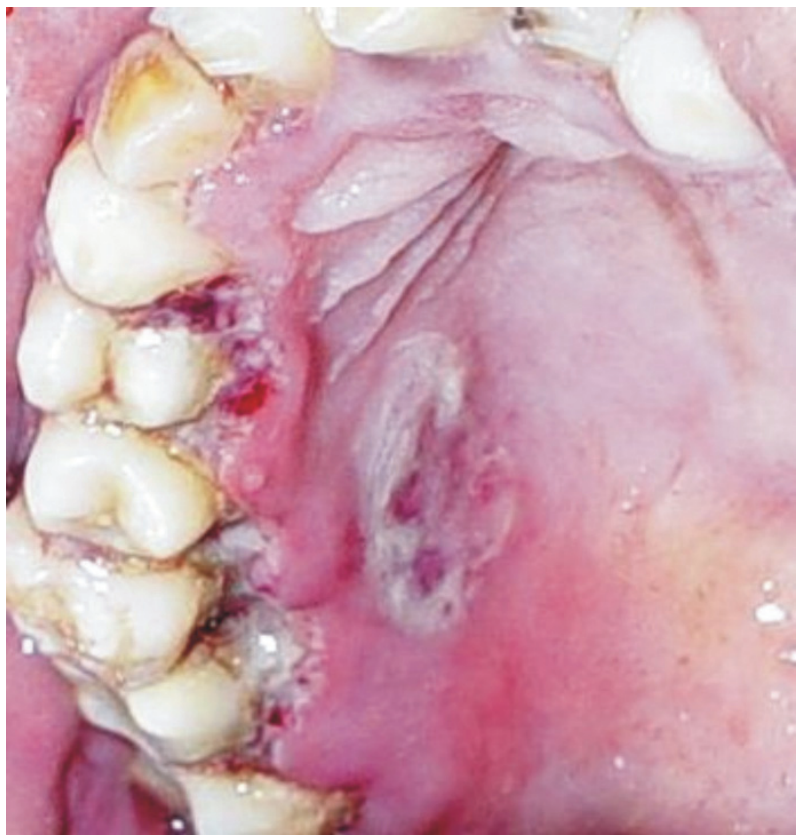

Figure 6 - Acute necrotizing ulcerative gingivitis also affecting the hard palate
Vincent's disease manifests as painful ulcers of the gingival margins, particularly the interdental areas. The ulcers may be localized or generalized and, when severe, they will give rise to cervical lymphadenopathy and, very rarely, to pyrexia and malaise. There is often oral malodor associated with Vincent's disease. Long-standing or recurrent disease may lead to destruction and loss of interdental papillae.

An ANUG-like disease termed cancrum oris (noma) (Figs. 7 and 8) can arise in profoundly malnourished children and adults. Unlike the ANUG in immunocompetent individuals, the ulcers of cancrum oris spread to the adjacent soft tissues, leading to necrosis of the lips and/or cheeks. Cancrum oris has most commonly been reported in children in Central Africa, where malnourishment arises from poverty that results from political and economical unrest. $^{35}$

An ANUG-like disorder that spreads to the underlying bone and adjacent soft tissues - termed necrotizing stomatitis - has been reported in a small number of patients with severe HIV disease. Occasionally, this disorder may be the first, and/or only clinical manifestation of HIV disease. ${ }^{36}$

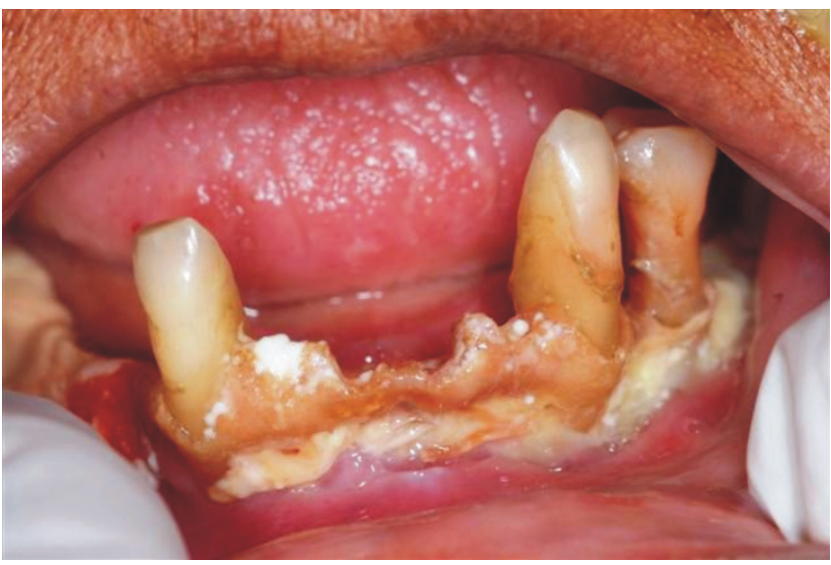

Figure 7 - Oral ulceration, bone exposure and tooth mobility/loss in cancrum oris

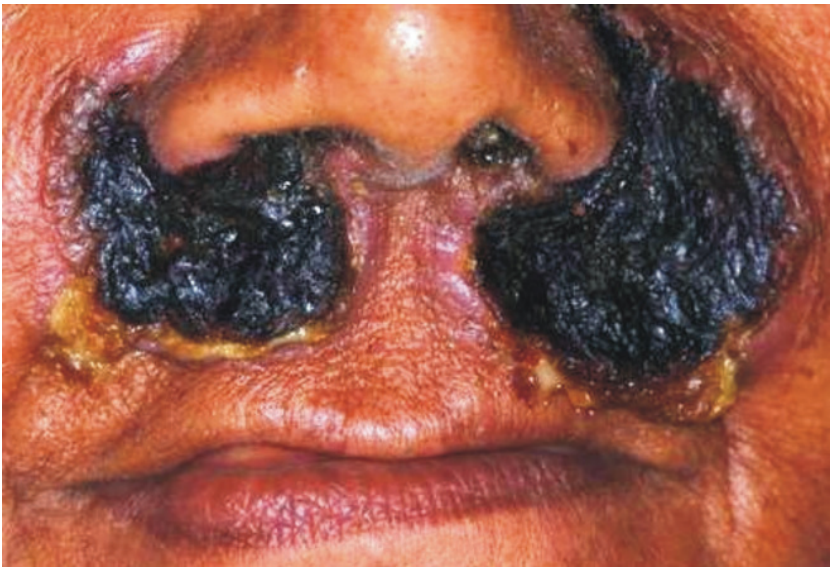

Figure 8 - Cutaneous necrosis secondary to cancrum oris 
Ulcers of ANUG typically resolve with the removal of deposits of plaque and calculus and the topical application of chlorhexidine gluconate mouth rinse $(0.2 \%)$ or gel $(1 \%)$. Systemic antimicrobials (e.g. metronidazole or phenoxymethyl penicillin) may be required when the gingivitis is profound and/or there is systemic upset. Cancrum oris also requires tissue debridement and correction of the underlying malnourishment; however, prognosis for the affected children is often poor. ${ }^{37}$ Post-healing fibrosis and scarring represent a significant complication of cancrum oris.

\section{Treponema pallidum}

The frequency of oral ulcers due to infective syphilis is likely to increase as a consequence of the rising number of subjects affected with Treponema pallidum; this may reflect changes in sexual attitudes and behavior, changing trends in HIV disease, and increased foreign travel. ${ }^{38}$ Oral ulcers can arise in primary, secondary or tertiary disease. In primary disease, a chancre can develop on the oral mucosa as a consequence of direct contact with an infective lesion. Ulcers of a primary infection typically arise on the upper (in females) or lower lip (in males) and manifest as a superficial to deep isolated ulcer that sometimes has a rolled edge. Occasionally, there can be isolated ulcers of the gingiva. ${ }^{39}$ The oral chancre typically resolves with antimicrobial therapy. ${ }^{40}$ Secondary syphilis can give rise to multiple areas of superficial papules and ulcers, some of the latter being serpiginous, and are thus termed snail-track ulcers. Tertiary disease may produce ulcers as a consequence of gumma formation, with the ulcers manifesting as isolated areas of chronic ulceration, sometimes with the destruction of the underlying soft and/or hard tissues (e.g. palate or tongue).

\section{Mycobacterial infection}

Primary oral infection of Mycobacterium tuberculosis is rare; ${ }^{41}$ more commonly, tuberculosis infection of the oral mucosa arises secondary to pulmonary disease. Tuberculosis typically presents as solitary, necrotic ulcers of the tongue. Infection by atypical mycobacteria (e.g. Mycobacterium avium complex) is rare, but may affect the oral mucosa or gingiva, usually in HIV-infected individuals. ${ }^{42}$

\section{Yeast and Fungal infections}

While Candida species, usually Candida albicans, are the most common fungal infection of the mouth, these rarely give rise to oral ulcers. Chronic mucocutaneous candidiasis (CMC) is one of the most common T-cell diseases, but the exact underlying defect is unknown. The disease usually starts in early childhood, but it may also start as late as early adolescence. Affected children have persistent oral thrush, napkin dermatitis, skin infections, dystrophic nails, alopecia, and thrush on the genital skin and oral mucous membranes. Candida granulomas rarely occur. Although fungal infection is the most important feature of this disease, in rare cases, recurrent bacterial infections and viral infections such as herpes simplex, herpes zoster and hepatitis can occur. This condition may occasionally give rise to ulcers of the dorsum of tongue..$^{43}$

Systemic mycoses can cause oral ulcers, typically in immunosuppressed hosts. In HIV disease, Aspergillus fumigatum may give rise to long-standing ulcers of the gingiva ${ }^{44}$ or oral mucosa as may Histoplasma capsulatum..$^{45}$ South America paracoccidiodomycosis (South American Blastomycosis) may give rise to large areas of ulcers reminiscent of oral SCC, with this infection arising in both immunocompetent and immunosuppressed individuals. ${ }^{46,47}$

\section{Idiopathic ulcers}

\section{Recurrent aphthous stomatitis}

The most common non-infectious and non-traumatic oral mucosal ulcerative disorder is recurrent aphthous stomatitis (RAS) (Fig. 9). The disease affects non-keratinized oral mucosa, especially the vestibulum, soft palate, tongue and sublingual area. It is clinically characterized by recurrent episodes of oral ulceration in an otherwise healthy individual. The ulcers arise every $4-12$ weeks and may be classified as minor, major, or herpetiform. The ulcers are superficial, rounded and have a yellow-colored slough with surrounding erythema. The ulcers of major RAS may cause scarring upon healing, and it has been suggested that ulcers of herpetiform RAS may coalesce to produce large areas of ulcers that heal with scarring. Rarely, major aph-

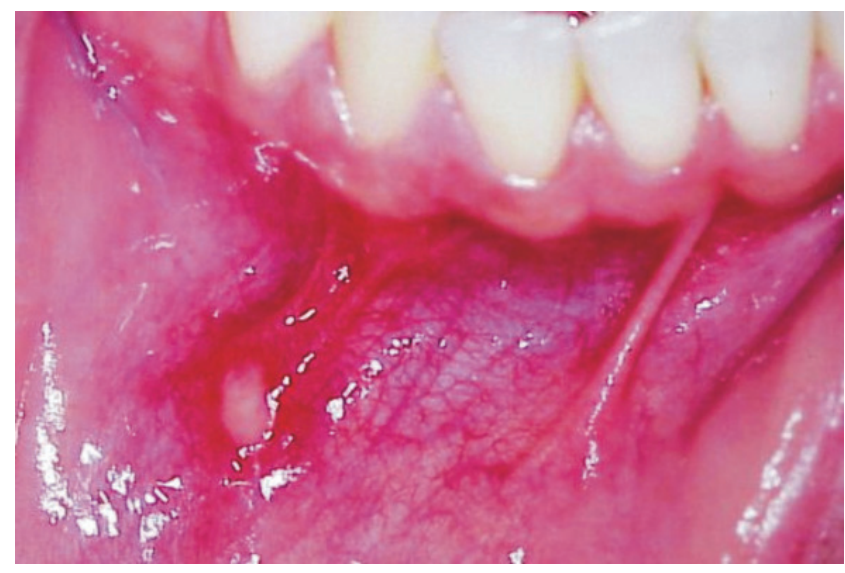

Figure 9 - Recurrent aphthous stomatitis affecting non-keratinised oral mucosa 
thous stomatitis causes tissue destruction (e.g. of the soft palate).

Undoubtedly, RAS has an immunologically mediated pathogenesis; however, the precise cause of RAS remains unclear. Reduced percentages of CD4 and CD8 cells in peripheral blood have been documented, but the results are still controversial. ${ }^{48}$ Suggested etiologies include idiopathic hematoma deficiency, cessation of tobacco smoking, and psychological stress, but there is little scientific evidence to support of any of these. While superficial ulcers similar to RAS may arise in gluten-sensitive enteropathy, ${ }^{49}$ the vast majority of patients with RAS have no clinical, gastroenterological, or serological features of this small bowel disorder. To date, no common viral or bacterial infection of the mouth has been implicated in the etiology of RAS. ${ }^{48}$ There is also no consistent association between Helicobacter pylori infection and RAS. ${ }^{50}$

Therapy for RAS is directed towards reducing the duration and/or frequency of episodes of ulceration..$^{51}$ Topical corticosteroids are used in the most cases; however, few of these have been found to be significantly effective in appropriate clinical studies. Chlorhexidine gluconate mouth rinse may be of some benefit (and has been evaluated in detail), ${ }^{52}$ but it has only limited clinical value in the management of RAS. Benzydamine hydrochloride spray or mouth rinse provides some symptomatic relief, but does not hasten ulcer healing. Although effective, systemic therapy with prednisone is rarely warranted, and the mechanism of this effect is unclear. ${ }^{53-55}$ Thalidomide is highly effective, but in view of the adverse side effects including teratogenicity and neurotoxicity, its routine application for such a recurrent and minor disorder is contraindicated. ${ }^{56}$

Ulcers similar to RAS are one of the cardinal features of Behcet's disease. The ulcers have only rarely been described in detail, but seem to have the same clinical features as RAS. A detailed discussion of Behcet's disease can be found elsewhere..$^{57}$ Other disorders that can give rise to RAS-like ulcers include a variant of Behcet's disease termed MAGIC syndrome, Sweet's syndrome, and HIV disease. ${ }^{58} \mathrm{~A}$ rare disorder in childhood that is characterized by pyrexia, pharyngitis, cervical lymphadenopathy and aphthous-like ulcers, sometimes termed PFAPA (periodic fever, aphthae, pharyngitis and adenitis), has also been described..$^{59}$

\section{Oral ulcers related to systemic disease}

\section{Gastrointestinal disease}

\section{Gluten-sensitive enteropathy}

Superficial oral mucosal ulcers similar to RAS may be a feature of $1-5 \%$ patients with undiagnosed, untreated gluten-sensitive enteropathy. ${ }^{60}$ The ulceration is presumably due to the associated hematinic deficiencies.

\section{Dermatitis herpetiformis and related disorders}

Oral lesions in dermatitis herpetiformis have been described only rarely. These may comprise oral mucosal vesicles, blood-filled blisters, irregular ulcers and desquamative gingitivitis. Linear IgA disease may likewise give rise to blood-filled vesicles or bullae, irregular ulcers and desquamative gingivitis. A long-term gluten-free diet (GFD) has been used successfully as a first-choice treatment for dermatitis herpetiformis $(\mathrm{DH}) .{ }^{61}$

\section{Crohn's disease and related disorders}

Oral ulcers arise in approximately $9 \%$ of patients with undiagnosed Crohn's disease and can be the first and/or only clinical features of this disorder. Crohn's disease is a systemic chronic inflammatory disorder that may involve any part of the gastrointestinal tract, including the oral cavity. The prevalence rates of oral manifestations vary between 5 and 20 per cent; however, in pediatric patients, the prevalence is much higher ( $48 \%$ to $80 \%$ ). ${ }^{62}$ Two types of oral ulcers can arise in orofacial granulomatosis (OFG) and Crohn's disease - chronic deep linear ulcers, usually of the buccal vestibules, which often have a rolled edge because of mucosal tags; and superficial oral mucosal ulcers (Fig. 10) presumably resulting from hematinic deficiency. The diagnosis of such ulcers requires establishing the presence of non-caseating granulomas and the exclusion of other granulomatous diseases, such as sarcoidosis.

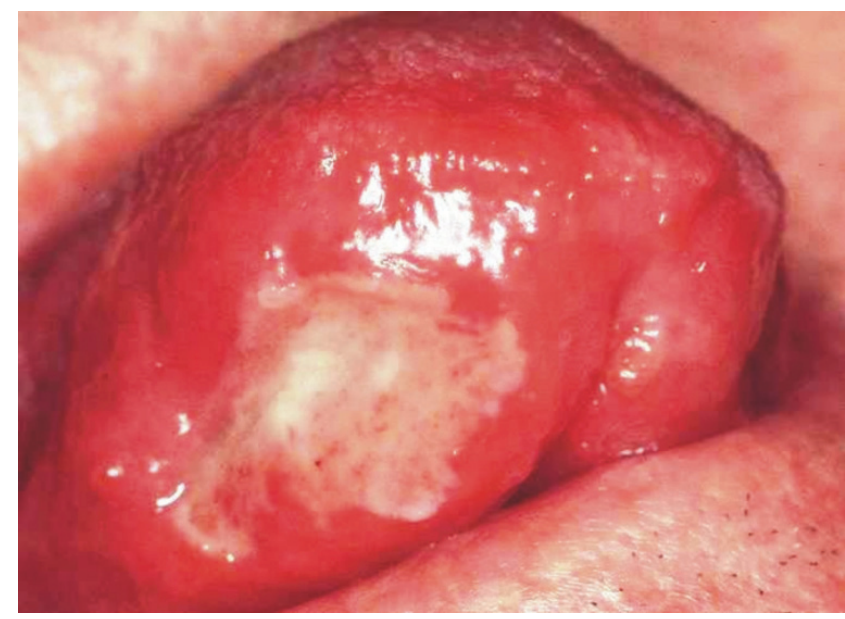

Figure 10 - Superficial and irregular oral ulceration of tongue in OFG

The precise relationship between $\mathrm{OFG}$ and gastrointestinal Crohn's disease remains unclear since there are few studies examining the gastrointestinal tract of chil- 
dren and adults with OFG. Certainly, there are reports of OFG as an initial presentation of Crohn's disease ${ }^{63,64}$ Similarly, OFG-like disease may be a feature of patients with concurrent gastrointestinal Crohn's disease. ${ }^{65,66}$ The human leukocyte antigen (HLA) haplotype of patients with OFG differs from that of Crohn's disease. ${ }^{67}$ The precise association between OFG and gastrointestinal Crohn's disease remains unknown.

\section{Ulcerative colitis}

Ulcerative colitis can give rise to either aphthous ulcers or to multiple pustules called pyostomatitis vegetans. The ulcers of the latter arise on the upper and lower anterior vestibules, the soft palate, and the posterior hard palate. Pyostomatitis vegetans tends to arise in patients with undiagnosed or active ulcerative colitis. Although most frequently associated with ulcerative colitis, pyostomatitis vegetans may occasionally arise in Crohn's disease. ${ }^{68}$ Pyoderma gangrenosum, manifesting as a solitary, necrotic mucosal ulcer has also been reported in the mouth in rare cases. ${ }^{69}$

\section{Others}

As discussed above, necrotizing sialometaplasia may arise secondary to palatal trauma in bulimia nervosa. Gastro-esophageal reflux does not cause oral ulceration, although it has been associated with erosion of the palatal aspects of the upper teeth. ${ }^{70}$

\section{Lichen planus}

Lichen planus is by far the most common dermatological disorder that gives rise to oral ulcers. Lichen planus is an immunologically mediated disorder that is histopathologically characterized by an intense dermal infiltrate of T-lymphocytes. The precise trigger for this immunological reaction is unclear. There is no evidence that the clinical features of idiopathic oral lichen planus are any different from those of the drug-associated diseases (Figs. 11 and 12). ${ }^{71}$

Similarly, although histopathological differences between idiopathic lichen planus and drug-related diseases have been described, there is profound inconsistency among the proposed pathological hallmarks of these two disorders. ${ }^{72}$ Drugs that may commonly give rise to lichen planus-like disease include sulphonyureas, non-steroidal antiinflammatory drugs, $\beta$-blockers, antimalarials, penicillamine and gold. Associations between hepatitis $\mathrm{C}$ virus and oral lichen planus probably reflect the epidemiology of hepatitis $\mathrm{C}$ virus infection and/or use of interferon- $\alpha .{ }^{73} \mathrm{~A}$ lichen planus-like disorder can also arise in chronic graftversus-host disease.

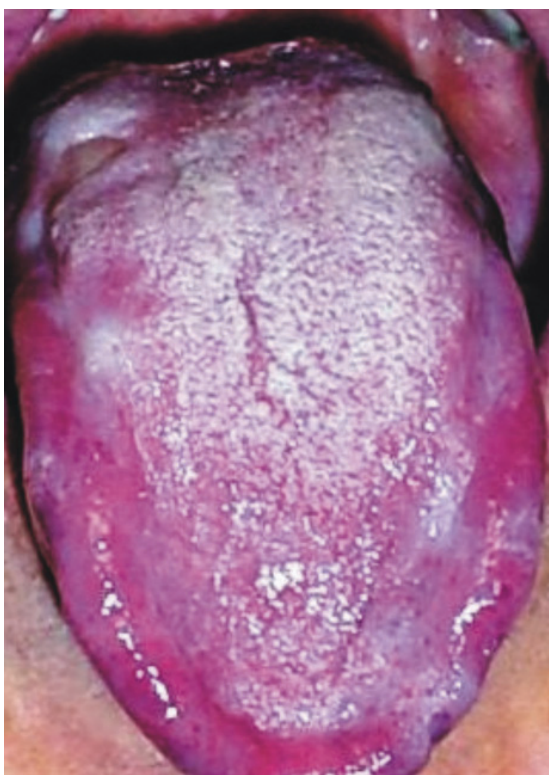

Figure 11 - Erosive non-striated oral lichen planus affecting the dorsum of the tongue

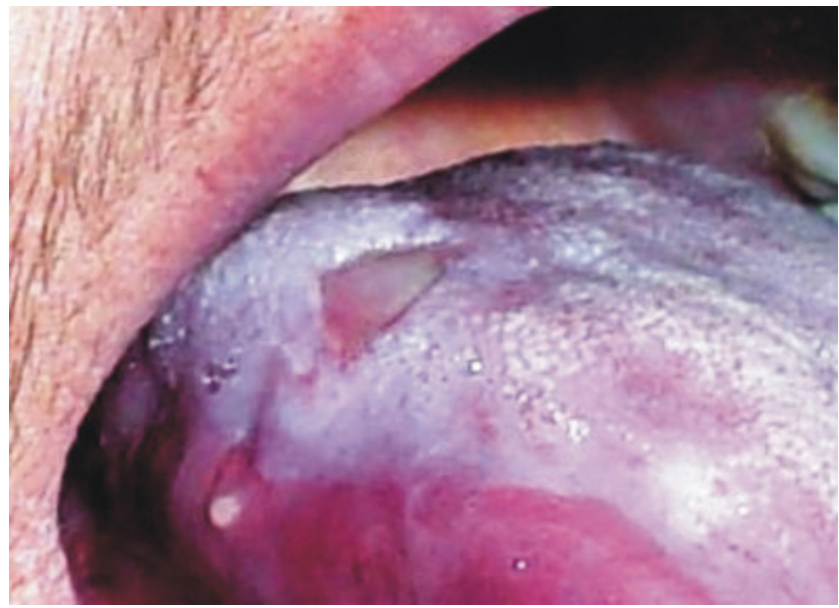

Figure 12 - Lateral view of erosive non-striated oral lichen planus affecting the dorsum of the tongue

Lichen planus only warrants treatment in patients who are having painful symptoms and/or signs of erosion, ulcers, or blister formation. Typical treatment involves topical corticosteroids, ${ }^{74}$ although severe cases may warrant local (e.g. topical tacrolimus) and systemic immunosuppressant therapy ${ }^{75,76}$, the latter of which does not have a strong evidence base.

Of note, it has been suggested that oral lichen planus may be potentially malignant. The evidence for this is generally based upon retrospective studies of large numbers of affected patients. It is suggested that approximately 1$3 \%$ of patients with long-standing lichen planus may develop oral SCC. ${ }^{77}$ Often, however, the descriptions have not detailed whether the tumor arose within existing lichen pla- 
nus, and no detailed prospective control studies of the development of oral SCC in long-standing lichen planus have ever been undertaken.

\section{Malignancy}

The common malignancies of the mouth may manifest as oral ulcers. SCC is the most common tumor of the mouth, typically manifesting as a solitary ulcer of the dorsum of tongue or floor of mouth (Fig. 13). The ulceration is locally destructive and, when affecting the tongue, may give rise to lingual and/or hypoglossal nerve damage with or without dysarthria or dysphagia. Gingival SCC may give rise to tooth mobility and, very rarely, to a pathological fracture of the mandible.

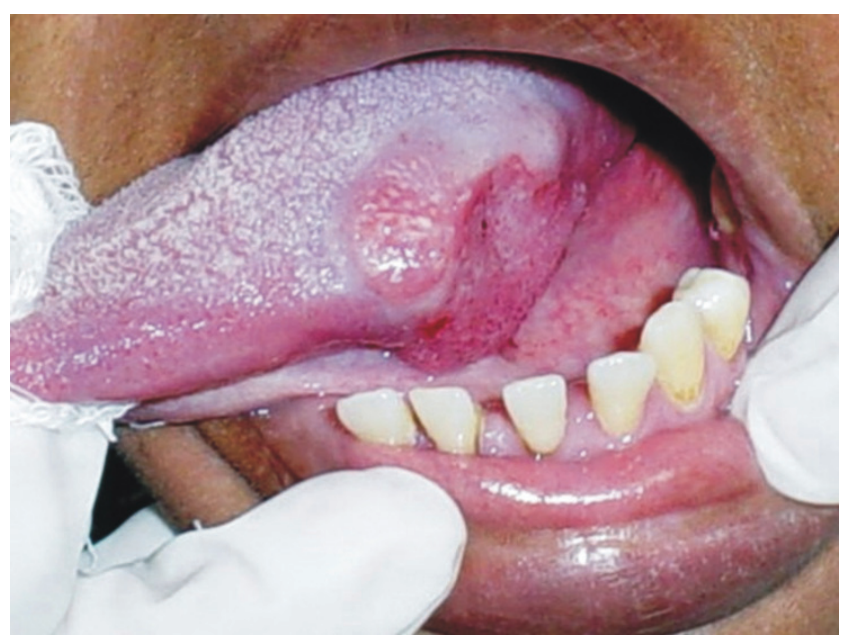

Figure 13 - Oral squamous cell carcinoma on the dorsum of the tongue and floor of the mouth.

Oral SCC remains one of the more common cancers worldwide, particularly in developing countries such as India. ${ }^{78-80}$ There is a rising frequency of oral SCC in the middle-aged adult population in the developed world. High tobacco (in any form) and alcohol consumption are the principal etiological factors of oral SCC. Other suggestive etiologies include human papilloma virus, malnourishment (in particular deficiencies of vitamins A and C), and possibly poor oral hygiene.

\section{Non-Hodgkin's lymphoma}

Non-Hodgkin's lymphoma may manifest as a solitary area of necrotic ulcers typically affecting the gingiva, palate and fauces. This tumor may arise de novo, but is often associated with iatrogenic immunosuppression in HIV disease. A detailed review of non-Hodgkin's lymphoma of the mouth can be found elsewhere. ${ }^{81} \mathrm{NK} / \mathrm{T}$-cell lymphoma tends to affect the upper anterior gingival and palate; this is a T-cell lymphoma, which is in contrast to most nonHodgkin's lymphoma of the mouth. ${ }^{82,83}$

\section{Drug therapy}

A wide range of drugs can give rise to ulcers of the oral mucosa. ${ }^{84}$ The mechanisms by which drugs cause oral ulcers include drug-induced neutropenia and anemia (e.g. cytotoxics), lichenoid disease (e.g. sulphanylureas, $\hat{a}$ blockers, gold, penicillamine), pemphigus (e.g. angiotensinconverting enzyme inhibitors), lupus, and $\operatorname{IgA}$ dermatoses.

\section{Leishmaniasis}

Cutaneous leishmaniasis, endemic in some parts of the Americas, is caused by Leishmania viannia and Leishmania mexicana species complexes. Infection with $L$. viannia species, particularly Leishmania viannia braziliensis, results in skin lesions that tend to be persistent and may be further complicated by mucocutaneous involvement. Mucosal leishmaniasis probably results from early hematogenous or lymphatic spread from cutaneous lesions. It causes destruction of the facial structure, which may lead to aspiration, infection, and even death. Mucosal leishmaniasis may appear at any time, from the first months after infection to decades afterward. Risk factors include large or multiple cutaneous lesions, male gender, and long-standing skin lesions for which adequate systemic treatment has not been administered. ${ }^{85}$

\section{RESUMO}

Leão JC, Gomes VB, Porter S. Lesões ulcerativas da boca: atualização para o clínico geral. Clinics. 2007;62(6):76980 .

A ulceração oral é uma queixa comum dos pacientes que são atendidos em ambulatórios. Com freqüência é difícil estabelecer um diagnóstico preciso e atingir o controle dos sinais e sintomas dos pacientes que apresentam ulceração oral. Os pacientes acometidos por ulceração oral são eventualmente encaminhados para os ambulatórios de gastroenterologia, entretanto, a maioria das úlceras não reflete doença gastrointestinal, e sim desordens sistêmicas que podem se apresentar com sinais e sintomas clínicos similares. O objetivo do presente artigo foi revisar aspectos 
da etiologia, diagnóstico e tratamento das desordens ulcerativas mais comuns da mucosa oral. Foi realizada uma busca no banco de dados MEDLINE da National Library of Medicine. A seleção dos artigos, coleta de dados e julgamento em termos da pertinência de inclusão foram realizadas pelos autores. Baseado na literatura pesquisada, foi concluído que existem várias doenças sistêmicas que podem apresentar sinais e sintomas clínicos semelhantes e o conhecimento de cada doença poderá guiar o clínico para uma intervenção apropriada.

UNITERMOS: Ulceração Oral. Medicina Oral. Lesões Orais. Estomatite Aftosa Recorrente. Ulceração Oral Recorrente

\section{REFERENCES}

1. Gandara-Rey JM, Diniz-Freitas M, Gandara-Vila P, Blanco-Carrion A, Garcia-Garcia A. Lesions of the oral mucosa in cocaine users who apply the drug topically. Med Oral. 2002;7(2): 03-7.

2. Blanksma CJ, Brand HS. Cocaine abuse: orofacial manifestations and implications for dental treatment. Int Dent J. 2005;55:365-9.

3. Goodger NM, Wang J, Pogrel MA. Palatal and nasal necrosis resulting from cocaine misure. Br Dent J. 2005;198:333-4.

4. Epstein JB, Klasser GD. Emerging approaches for prophylaxis and management of oropharyngeal mucositis in cancer therapy. Expert Opin Emerg Drugs. 2006;11:353-73.
5. Dorr W, Reichel S, Spekl K. Effects of Keratinocyte growth factor (palifermin) administration protocols on oral mucositis (mouse) induced by fractionated irradiation. Radiother Oncol. 2005;75:99-105.

6. Fleisher G, Dorr W. Amelioration of early radiation effects in oral mucosa (mouse) by intravenous or subcutaneous administration of amifostine. Strahlenther Onkol. 2006;182:567-75.

7. Kelly C, Lindahl S, Malmberg L, Reizenstein J, Alenius M, Lewensohn $\mathrm{R}$. Therapeutic efficacy by recombinant human granulocyte monocytecolony stimulating factor on mucositis occuring in patients with oral and oropharynx tumors treated with curative radiotherapy: a multicenter open randomized phase III study. Med Oncol. 2005;22:247-56. 
8. Robinson JA, Shankaramma Sc, Jetter P, Kienze U, Schwendener RA, Vrijbloed JW, Obrecht D. Properties and structure-activity studies of cyclic beta-hairpin peptidomimetics based on the cationic antimicrobial peptide protegrin I. Bioorg Med Chem. 2005;13:2055-64.

9. Kominek P, Blasch P. Necrotizing sialometaplasia: a potential diagnostic pitfall. Ear Nose Throat J. 2006;85:604-5.

10. Solomon LW, Merzianu M, Sullivan M, Rigual NR. Necrotizing sialometaplasia associated with bulimia: case report and literature review. Oral Surg Oral Med Oral Pathol Oral Radiol Endod. 2007;103:39-42.

11. Bunzli D, Wietlisbach V, Barazzoni F, Sahki R, Meylan PR. Soroepidemiology of herpes simplex virus type 1 and 2 in Western and Southern Switzerland in adults aged 25-74 in 1992-93: a populationbased study. BMC Infect Dis. 2004;174:10.

12. Malkin JE. Epidemiology of genital herpes simplex virus infection in developed countries. Herpes. 2004;11 suppl 1:2A-23A.

13. Ficarra G. Oral ulcers in HIV-infected patients: an update on epidemiology and diagnosis. Oral Dis. 1997;3 suppl 1:S183-9.

14. Kleymann G. Agents and strategies in development for improved management of herpes simplex virus infection and disease. Expert Opin Investig Drugs. 2005;14:135-61.

15. Wu JJ, Pang KR, Huang DB, Tyring SK. Advances in antiviral therapy. Dermatol Clin. 2005;23:313-22.

16. Van der Pij1 JW. Prevention of genital ulcerations during treatment with foscarnet. Presse Med. 1992;21:395.

17. Morrel EM, Spruance SL, Goldberg DI and Iontophoretic Acyclovir Cold Sore Study Group. Topical iontophoretic administration of acyclovir for the episodic treatment of herpes labialis: a ramdomized, double-blind, placebo-controlled, clinic-initiated trial. Clin Infect Dis. 2006;43:460-7.

18. Sarisky RT, Bacon T, Boon R, Locke L, Nguyen TT, Leary J, et al. Penciclovir susceptibilities of herpes simplex virus isolates from patients using penciclovir cream for treatment of recurrent herpes labialis. Antimicrob Agents Chemother. 2002;46:2848-53.

19. Kokuba H, Imafuku S, Huang S, Aurelian L, Burnett JW. Erythema multiforme lesions are associated with expression of a herpes simplex virus (HSV) gene and qualitative alterations in the HSV-specific T-cell response. Br J Dermatol. 1998;138:952-64.

20. Szczepanski T, De Vaan GA, Beishuizen A, Bogman J, Jansen MW, van Wering ER et al. Acute lymphoblastic leukemia followed by a clonallyunrelated EBV-positive non-Hodgkin lymphoma and a clonally-related myelomonocytic leukemia cutis. Pediatr Blood Cancer. 2004;42:343-9.

21. Fluckiger R, Laifer G, Itin P, Meyer B, Lang C. Oral hairy leukoplakia in a patient with ulcerative colitis. Gastroenterology. 1994;106:506-8.

22. Firth NA, Rich AM, Reade PC. Oral mucosal ulceration due to cytomegalovirus associated with human immunodeficiency virus infection. Case report and brief review. Aust Dent J. 1994;39:273-5.

23. Flaitz CM, Nichols CM, Hicks MJ. Herpesviridae-associated persistent mucocutaneous ulcers in acquired immunodeficiency syndrome. A clinicopathologic study. Oral Surg Oral Med Oral Pathol Oral Radiol Endod. 1996;81:433-41

24. Lager I, Altini M, Coleman H, Ali H. Oral Kaposi's sarcoma: a clinicopathologic study from South Africa. Oral Surg Oral Med Oral Pathol Oral Radiol Endod. 2003;96:701-10.
25. Reichart PA, Schiodt M. Non-pigmented oral Kaposi's sarcoma (AIDS) Report of two cases. Int J Oral Maxillofac Surg. 1989;18:197-9.

26. Diz DP, Ocampo HA, Miralles AC, Vazquez GE, Martinez VC. Regression of AIDS-related Kaposi's sarcoma following ritonavir therapy. Oral Oncol. 1998;34:236-8.

27. Le Bourgeois JP, Frikha H, Piedbois P, Le Pechoux C, Martin L, Haddad E. Radiotherapy in the management of epidemic Kaposi's sarcoma of the oral cavity, the eyelid and the genitals. Radiother Oncol. 1994;30:263-6.

28. Ramirez-Amador V, Esquivel-Pedraza L, Lozada-Nur F, et al Intralesional vinblastine vs. $3 \%$ sodium tetradecyl sulfate for the treatment of oral Kaposi's sarcoma. A double blind, randomized clinical trial. Oral Oncol. 2002;38:460-7.

29. Scully C, Laskaris G, Pindborg J, Porter SR, Reichart P. Oral manifestations of HIV infection and their management: II. Less common lesions. Oral Surg Oral Med Oral Pathol. 1991;71:167-71.

30. Scully C, Laskaris G, Pindborg J, Porter SR, Reichart P. Oral manifestations of HIV infection and their management: I. More common lesions. Oral Surg Oral Med Oral Pathol. 1991;71:158-66.

31. MacPhail LA, Greenspan JS. Oral ulceration in HIV infection: investigation and pathogenesis. Oral Dis. 1997;3:190-3.

32. Di Alberti L, Porter SR, Speight PM, Scully CM, Zakrzewska JM, Williams IG et al. Detection of human herpesvirus-8 DNA in oral ulcer tissues of HIV-infected individuals. Oral Dis. 1997;1:133-4.

33. Ramirez-Amador VA, Esquivel-Pedraza L, Ponce-de-Leon S, ReyesTeran G, Gonzalez-Guevara M, Ponce-de-Leon S et al. Thalidomide as therapy for human immunodeficiency virus-related oral ulcers: a doubleblind placebo-controlled clinical trial. Clin Infect Dis. 1999;28:892-4.

34. Baccaglini L, Atkinson JC, Patton LL, Glick M, Ficarra G, Peterson DE. Managment of oral lesions in HIV-positive patients. Oral Surg Oral Med Oral Pathol Oral Radiol Endod. 2007;103:21-23.

35. Okolo S, Chukwu G, Eqbuonu I, Ezeogu F, Onwuanaku C, Adeleke O et al. Oral hygiene and nutritional status of children aged 1-7 years in a rural community. Ghana Med J. 2006;40: 22-5.

36. Enwonwu CO, Falkler WA Jr, Idigbe EO, Afolabi BM, Ibrahim M, Onwujekwe D et al. Pathogenesis of cancrum oris (noma): confounding interactions of malnutrition with infection. Am J Trop Med Hyg. 1999;60:223-32.

37. Jones AC, Gulley ML, Freedman PD. Necrotizing ulcerative stomatitis in human immunodeficiency virus-seropositive individuals: a review of the histopathologic, immunohistochemical, and virologic characteristics of 18 cases. Oral Surg Oral Med Oral Pathol Oral Radiol Endod. 2000;89:323-32.

38. Adekeye EO, Ord RA. Cancrum oris: principles of management and reconstructive surgery. J Maxillofac Surg. 1983;11:160-70.

39. Alam F, Argiriadou AS, Hodgson TA, Kumar N, Porter SR. Primary syphilis remains a cause of oral ulceration. Br Dent J. 2000;189:352-4.

40. Steiner M, Alexander WN. Primary syphilis of the gingiva. Report of two cases. Oral Surg Oral Med Oral Pathol. 1966;21:530-5.

41. Schofer H. Syphilis. Clinical aspects of Treponema pallidum infection. Hautarzt. 2004;55:112-9. 
42. Ajay GN, Laxmikanth C, Prashanth SK. Tuberculous ulcer of tongue with oral complications of oral antituberculosis therapy. Indian J Dent Res. 2006;17:87-90.

43. Ilyas SE, Chen FF, Hodgson TA, Speight PM, Lacey CJ, Porter SR. Labial tuberculosis: a unique cause of lip swelling complicating HIV infection. HIV Med. 2002;3:283-6.

44. Sathis Kumar T, Xavier SJ, Renu G. Chronic mucocutaneous candidiasis in a child. Indian J Dermatol Venerol Leprol. 2005;71:432-3.

45. Myoken Y, Sugata T, Kyo TI, Fujihara M. Pathological features of invasive oral aspergillosis in patients with hematologic malignancies. J Oral Maxillofac Surg. 1996;54:263-70.

46. Loh FC, Yeo JF, Tan WC, Kumarasinghe G. Histoplasmosis presenting as hyperplastic gingival lesion. J Oral Pathol Med. 1989;18:533-6.

47. Scully C, de Almeida OP. Orofacial manifestations of the systemic mycoses. J Oral Pathol Med. 1992;21:289-94.

48. Ranganathan K, Hemalatha R. Oral lesions in HIV infection in developing countries: an overview. Adv Dent Res. 2006;19:63-8.

49. Moraru RA, Grossman ME. Palatal necrosis in an AIDS patient: a case of mucormycosis. Cutis. 2000;66:15-8.

50. Porter SR, Scully C, Pedersen A. Recurrent aphthous stomatitis. Crit Rev Oral Biol Med. 1998;9:306-21.

51. Srinivasan U, Weir DG, Feighery C, O’Farrelly C. Emergence of classic enteropathy after longstanding gluten sensitive oral ulceration. BMJ. 1998;316:206-7.

52. Porter SR, Barker GR, Scully C, Macfarlane G, Bain L. Serum IgC antibodies to Helicobacter pylori in patients with recurrent aphthous stomatitis and other oral disorders. Oral Surg Oral Med Oral Pathol Oral Radiol Endod. 1997;83:325-8.

53. Porter S, Scully C. Aphthous ulcers: recurrent. Clin Evid. 2002;8:1397403.

54. Hunter L, Addy M. Chlorhexidine gluconate mouthwash in the management of minor aphthous ulceration. A double-blind, placebocontrolled cross-over trial. Br Dent J. 1987;162:106-10.

55. Barrons RW. Treatment strategies for recurrent oral aphthous ulcers. Am J Health Syst Pharm. 2001;58:41-50.

56. MacPhail L. Topical and systemic therapy for recurrent aphthous stomatitis. Semin Cutan Med Surg. 1997;16:301-7.

57. Eisen D, Lynch DP. Selecting topical and systemic agents for recurrent aphthous stomatitis. Cutis. 2001;68:201-6.

58. Shetty K. Thalidomide in the management of recurrent aphthous ulcerations in patients who are HIV-positive: a review and case reports. Spec Care Dentist. 2005;25:236-41.

59. Arayssi T, Hamdan A. New insights into the pathogenesis and therapy of Behcet's disease. Curr Opin Pharmacol. 2004;4:183-8.

60. Femiano F, Gombos F, Scully C. Sweet's syndrome: recurrent oral ulceration, pyrexia, thrombophlebitis, and cutaneous lesions. Oral Surg Oral Med Oral Pathol Oral Radiol Endod. 2003;95:324-7.

61. Feder HM Jr. Periodic fever, aphthous stomatitis, pharyngitis, adenitis: a clinical review of a new syndrome.Curr Opin Pediatr. 2000;12:253-6.
62. Nowak M, Dziechciarz P, Dwilewicz-Trojaczek J. The frequency of coeliac disease occurrence in patients with recurrent aphthous stomatitis (RAS) - preliminary report. Wiad Lek. 2002;55:542-6.

63. O'Regan E, Bane A, Flint S, Timon C, Toner M. Linear IgA disease presenting as desquamative gingivitis: a pattern poorly recognized in medicine. Arch Otolaryngol Head Neck Surg. 2004;130:469-72.

64. Harty S, Fleming P, Rowland M, Crushell E, McDermott M, Drumm B, et al. A prospective study of the oral manifestations of Crohn's disease. Clin Gastroenterol Hepatol. 2005;3:886-91.

65. Sanderson J, Nunes C, Escudier M, Barnard K. Oro-facial granulomatosis: Crohn's disease or a new inflamatory bowel disease? Inflamm Bowel Dis. 2005;11:840-6.

66. Kauzman A, Quesnel-Mercier A, Lalonde B. Orofacial granulomatosis: 2 cases reports and literature review. J Can Dent Assoc. 2006;71:325-9.

67. Orosz M, Sonkodi I. Oral manifestations in Crohn's disease and dental management. Fogorv Sz. 2004;97:113-7.

68. Tyldesley WR. Oral Crohn's disease and related conditions. Br J Oral Surg. 1979;17:1-9.

69. Gibson J, Neilly JB, Wray AP, Evans TJ, MacKenzie JR, McKillop JH. [99Tcm]-HMPAO leucocyte labelling in orofacial granulomatosis and gastrointestinal Crohn's disease in childhood and early adulthood. Nucl Med Commun. 2000;21:155-8

70. Ficarra G, Cicchi P, Amorosi A, Piluso S. Oral Crohn's disease and pyostomatitis vegetans. An unusual association. Oral Surg Oral Med Oral Pathol. 1993;75:220-4.

71. Hernandez-Martin A, Arias-Palomo D, Hermida G, Gutiérrez-Ortega MC, Ramírez-Herrera M, Rodríguez-Vegas M et al. Oral pyoderma gangrenosum. Br J Dermatol. 2003;149:663-4.

72. Lackey MA, Barth J. Gastroesophageal reflux disease: a dental concern. Gen Dent. 2003;51:250-4.

73. Scully C, Beyli M, Ferreiro MC, Ficarra G, Gill Y, Griffiths M et al Update on oral lichen planus: etiopathogenesis and management. Crit Rev Oral Biol Med. 1998;9:86-122.

74. McCartan BE, McCreary CE. Oral lichenoid drug eruptions. Oral Dis. 1997;3: 58-63.

75. Bratel J, Dahlgren U, Simark MC, Jontell M. The frequency of different T-cell receptor V-families in oral lichen planus and lichenoid contact lesions: an immunohistochemical study. J Oral Pathol Med. 1998;27:415-9.

76. Nagao Y, Sata M, Ide T. Development and exacerbation of oral lichen planus during and after interferon therapy for hepatitis C. Eur J Clin Invest. 1996;26:1171-4

77. Hegarty AM, Hodgson TA, Lewsey JD, Porter SR. Fluticasone propionate spray and betamethasone sodium phosphate mouthrinse: a randomized crossover study for the treatment of symptomatic oral lichen planus. J Am Acad Dermatol. 2002;47:271-9.

78. Kaliakatsou F, Hodgson TA, Lewsey JD, Hegarty AM, Murphy AG, Porter SR. Management of recalcitrant ulcerative oral lichen planus with topical tacrolimus. J Am Acad Dermatol. 2002;46:35-41

79. Porter SR, Scully C, Eveson JW. The efficacy of topical cyclosporin in the management of desquamative gingivitis due to lichen planus. Br J Dermatol. 1993;129:753-5. 
80. Rodstrom PO, Jontell M, Mattsson U, Holmberg E. Cancer and oral lichen planus in a Swedish population. Oral Oncol. 2004;40:131-8.

81. Silverman S, Bhargava K, Smith LW, Malaowalla AM. Malignant transformation and natural history of oral leukoplakia in 57,518 industrial workers of Gujarat, India. Cancer. 1976;38:1790-5.

82. Gupta PC, Mehta FS, Pindborg JJ. Intervention study for primary prevention of oral cancer among 36000 Indian tobacco users. Lancet. 1986;1:1235-9.
83. Rajkumar T, Sridhar H, Balaram P. Oral cancer in Southern India: the influence of body size, diet, infections and sexual practices. Eur J Cancer Prev. 2003;12:135-43.

84. Porter S, Scully C. HIV: the surgeon's perspective: Part 3. Diagnosis and management of malignant neoplasms. Br J Oral Maxillofac Surg. 1994;32:241-7.

85. Scope A, Trau H, Bakon M, Yarom N, Nasereddin A, Schwartz E. Imported mucosal leishmaniasis in a traveler. Clin Infect Dis. 2003;37:83-7. 